\title{
BUSINESS ENTERPRISES
}

\section{AND CORPORATE GOVERNANCE: \\ CONTEMPORARY TRANSFORMATION \\ PROCESSES}

Молодковець І. А., заступник начальника відділу доходів департаменту бюджету та фінансів Житомирська міська рада м. Житомир, Україна

DOI: https://doi.org/10.30525/978-9934-26-123-7-2

\section{УПРАВЛІННЯ ГРОШОВИМИ ПОТОКАМИ}

Раціональне управління грошовими потоками в сучасних умовах дозволяє вирішити головне завдання підприємства - підвищення ефективності його функціонування, та, водночас, забезпечує фінансову рівновагу та безперервність діяльності підприємства, прискорює капіталообіг, знижує ризик неплатоспроможності та дозволяе отримати кращі економічні показники.

Підтримка фінансової рівноваги та забезпечення збільшення основного показника - вартості підприємства $€$ запорукою економічного зростання підприємства. Тому аналіз ефективності управління грошовими потоками $\epsilon$ першочерговим та досить актуальним. 
Фінансова спроможність підприємства забезпечити дотримання своєчасності виконання власних поточних зобов'язань шляхом формування на основі грошових потоків необхідного фонду коштів у визначений момент часу та із заданою абсолютною величиною визначається рівнем фінансового забезпечення (покриття) потреби підприємства у капіталі. Результатом такої спроможності підприємства та іï кількісним вираженням $є$ рівень його ліквідності (можливість швидкого формування фонду грошових коштів без значних фінансових втрат) і платоспроможності (можливість своєчасного та повного погашення зобов'язань). Підтримання належного рівня платоспроможності та ліквідності суб'єкта господарювання досягається шляхом управління грошовими потоками.

Управління грошовими потоками - це складова частина загальної системи управління фінансами підприємства. Управління грошовими потоками підприємства - це складний неперервний циклічний процес формування послідовних етапів прийняття і реалізації стратегічних та оперативно-тактичних рішень, спрямованих на організацію руху грошових потоків у часі та просторі. Процес управління потоками грошових коштів представляє собою постійний моніторинг відхилень реального руху грошових коштів від планових показників та застосування заходів по усуненню таких відхилень. В свою чергу, планові показники повинні враховувати пропозиції щодо ефективного використання грошових коштів (наприклад, в напрямку прискорення їх обороту) [3, с. 82]. 
Основною метою управління грошовими потоками $є$ забезпечення фінансової рівноваги підприємства в процесі його розвитку шляхом збалансування обсягів надходжень i витрат коштів та їхньої синхронізації в часі.

Для ухвалення ефективних фінансово-господарських рішень щодо управління грошовими потоками важливим $є$ використання дієвого організаційно-економічного механізму, що являє собою систему взаємопов'язаних між собою елементів, яка визначає і забезпечує реалізацію комплексу заходів на кожному із етапів управління грошовими потоками. В структурі механізму виокремлено методи, важелі, організаційно-правове, інформаційне та програмнотехнічне забезпечення.

Грошовий потік підприємства являє собою сукупність розподілених у часі надходжень і виплат коштів, вироблених його господарською діяльністю.

Сутність ефективного управління грошовими потоками на підприємстві визначається за допомогою наступних чинників:

1. Грошові потоки обслуговують здійснення господарської діяльності підприємства практично у всіх іiі аспектах. Грошовий потік можна представити як систему «фінансового кровообігу» господарського організму підприємства.

2. Фінансова рівновага забезпечує ефективне управління грошовими потоками.

3. Правильне формування грошових потоків сприяє підвищенню ритмічності здійснення операційного процесу підприємства. 
4. Ефективне управління грошовими потоками дозволяє скоротити потреби підприємства в позиковому капіталі. Активно управляючи грошовими потоками, можна забезпечити більш раціональне й заощадливе використання власних фінансових ресурсів, сформованих із внутрішніх джерел, знизити залежність темпів розвитку підприємства від позикового капіталу.

5. Управління грошовими потоками є важливим фінансовим важелем забезпечення збільшення обороту капіталу підприємства.

6. Зниження ризику неплатоспроможності підприємства відбувається безпосередньо за допомогою ефективного управління грошовими потоками. Навіть у підприємств, що успішно здійснюють свою діяльність і отримують необхідну для розвитку суму прибутку, неплатоспроможність може виникати як наслідок незбалансованості різних видів грошових потоків у часі. Синхронізація надходження i виплат коштів, що відбувається безпосередньо в процесі управління грошовими потоками підприємства, дозволяє усунути фактор неплатоспроможності.

7. Активні форми управління грошовими потоками дають можливість підприємству отримувати прибуток, створений його грошовими активами.

У практиці існують положення щодо організації ефективності управління грошовими потоками підприємства:

- грошові потоки не можуть утворюватися в результаті пасивної економічної поведінки підприємства;

- грошові потоки є невід'ємною частиною фінансового та операційного циклів, що в свою чергу вимагає пого- 
дження фінансових питань між усіма ланками курування фінансами підприємства;

- управління грошовими потоками потребує відповідного інформаційного доповнення системи для прийняття управлінських рішень;

- однозначність трактування прийнятих фінансових рішень, змістовне доведення їх до виконавців та надання адекватного зворотного зв'язку - моніторингу, перегляду та корегування фінансових рішень - $є$ невід'ємним положенням управління грошовими потоками [4, с. 322].

Управління грошовими потоками включає реалізацію наступних етапів:

1) планування та прогнозування грошових потоків i складання відповідних внутрішніх фінансових документів;

2) імплементація бюджету грошових потоків, що $\epsilon$ невід'ємною складовою системи бюджетів на підприємстві, як процес його безпосереднього дотримання при організації операційної, інвестиційної, фінансової діяльності;

3) контролінг виконання бюджету грошових потоків та планових показників звіту про рух грошових коштів;

4) корегування планових величин відповідно до зміни зовнішніх і внутрішніх умов реалізації бюджету грошових потоків [1].

Враховуючи викладене вище, можна дійти висновку, що правильно організована система управління грошовими потоками дає можливість підвищити рівень виробництва та прибутковість підприємства. Від якості та ефективності процесу управління грошовими потоками залежить не тільки фінансова стійкість підприємства в даний період 
часу, а й безпосередньо змога подальшого розвитку, досягнення фінансового успіху на майбутнє.

\section{Література:}

1. Менеджмент : учебник / О.С. Виханский, А.И. Наумов. 5-е изд. стереотипн. - М. : Магистр : ИНФРА-М, 2014. - 576 с.

2. Фінансовий менеджмент : навч. посіб. / [Васьківська К.В., Сич О.А.] . - Львів : «ГАЛИЧ-ПРЕС», 2017. - 236 с.

3. Фінансовий менеджмент : підручник / Д.І. Дема, Л.М. Дорохова, О.М. Віленчук [та ін.] - Житомир : ЖНАЕУ, 2018. - 320 с.

4. Ясишена В. Сутність грошових потоків підприємств та їх класифікація [Текст] / В. Ясишена // Економічний аналіз. - 2014. № 2. - C. 321-324. 